\title{
FACTORS INFLUENCING INDONESIAN TOURISt TRAVELLING TO TURKEY DURING THE PANDEMIC
}

\author{
by \\ Dina Hariani \\ Sekolah Tinggi Pariwisata Bogor \\ Email: bhi.dinahariani@gmail.com
}

\begin{abstract}
According to data from the UNWTO, Indonesians made around 11.7 million outbound departures in 2019. The growth in outbound travel in Indonesia was halted by the COVID-19 pandemic, which resulted in global travel restrictions. In June 2020, Turkey has announced a Safe Tourism Certification program, launched to coincide with the start of the 2020 summer season to increase the number of tourists. In July 2020, travel agencies in Indonesia started promoting Turkey tour packages. Since travel agents sold packages to Turkey, the number of Indonesian tourists going to Turkey during the pandemic has increased. This study explores the Turkey Safe Tourism program and factors that influence Indonesian tourists to travel during the pandemic. Using qualitative descriptive methods and for achieving the research objectives the data were collected from secondary sources; researches, journals, articles, and statistical reports. Primary data were collected through interviews and observations of tourists and travel agent guides who already went to Turkey during the pandemic. As the result of this study, Turkey is ready to welcome tourists. Indonesia tourists who came to visit Turkey felt safe because Turkey's conditions are quiet from tourists and health protocols are running well. Travel agencies in Indonesia sell Turkey tour packages because there is demand and purchase. A combination of pent-up wanderlust and lockdown fatigue is driving demand for international travel among Indonesian tourists. Factors that influenced Indonesian tourist travel to Turkey are security, cleanliness priorities, discounted prices, and flexibility.
\end{abstract}

Keyword: Indonesian Tourist, Pandemic, Safe Tourism \& Turkey

\section{INTRODUCTION}

In 2019, Indonesians spent around 11.3 billion U.S. dollars during their outbound travels. Indonesians made around 11.7 million outbound departures in 2019 (Statista, 2020). The Covid-19 case in Indonesia began to affect the tourism industry in March 2020 because the Indonesian government declared Covid-19 as a national disaster. Work from home policies, schools from home, limited operating hours, closure of public places, and restrictions on crowding have caused the tourism industry such as restaurants, hotels, planes, and tour agencies to suffer losses. In May 2020 domestic and international flights are opened but only those who meet the requirements can travel. In July 2020, airports in Indonesia started safe travel campaigns. In August
2020, the number of flights in Indonesia reached the highest number of flights since the pandemic. International flights at SoekarnoHatta Airport became increasingly busy in the fourth quarter of 2020, in October which is the first month of the fourth quarter of 2020, the number of international flight passengers at Soekarno-Hatta Airport reached 77,853 people or an average of around 2,500 people / day. The 5 airlines that carry the most international routes passengers are Garuda Indonesia 12,020 people, Qatar Airways 9,427 people, Emirates 8,757 people, Turkish Airlines 5,494 people, and China Airlines 4,948 people. The busiest international routes in October 2020 are from and to Doha 9,427 people, Dubai 8,757 people, Taipei 6,281 people, Seoul 5,884 people, and Istanbul 5,494 people (Angkasa Pura, 2020). 
Based on UNWTO World Tourism Barometer (2020), International tourist arrivals (overnight visitors) fell by 72 in JanuaryOctober 2020 over the same period last year. The decline in the first ten months of the year represents 900 million fewer international tourist arrivals compared to the same period in 2019 and translates into a loss of US\$ 935 billion in export revenues from international tourism, more than 10 times the loss in 2009 under the impact of the global economic crisis. UNWTO's extended scenarios for 2021-2024 point to a rebound in international tourism by the second half of 2021. Nonetheless, a return to 2019 levels in terms of international arrivals could take $2 \frac{1}{2}$ to 4 years.

In June 2020, Turkey has announced a Safe Tourism Certification program, launched to coincide with the start of the 2020 summer season to increase the number of tourists. Indonesia travel agents were visited Turkey to observe the Safe Tourism Certification in Turkey. After they visited Turkey they were certain it is safe to travel to Turkey during the pandemic and they start selling the Turkey Tour packages to Indonesian tourists. Based on the author's observations through Instagram of tour and travel agents in Indonesia, since Turkey opened its country to Indonesian tourists, travel agents have started making packages for tours to Turkey.

\section{LITERATURE REVIEW Travel Motivation}

According to George (2004) as well as March and Woodside (2005) travel motivations can be considered as one of the most important psychological influences of tourist behavior. Motivations are the inner state of a person, or certain needs and wants of a person, which forces them to act or behave in a specific way and thus sustaining human behavior and energy levels of the human body (Decrop, 2006; George, 2004). Maslow's theory is one of the most frequent used to explain the premise of motivation. Maslow uses five sets of goals which are also referred to as basic needs: physiological needs, safety needs, social needs, self-esteem and self-actualization (Tikkanen, 2007). Tourists may need to escape, relax, to gain relief of physical- and mental tension and for typical reasons. Crompton (as cited by Saayman, 2006) identified seven sociopsychological factors which motivate a tourist to travel: escape from an everyday environment, discovery and evaluation of oneself, relaxing or participation in recreational activities, gaining a certain level of prestige, for the purpose of regression, strengthening family ties and facilitating their level of social interaction.

According to Yoon and Usyal (2005), someone's tour motivation is divided into two namely the push and pull factors. Push factors are factors that are related to one's desire to take a trip that comes from within him (intrinsic motivation), while the pull factors are external factors (extrinsic motivation) that motivate tourists to take a tour. The pull factor related to the quality of destinations that are attractive to tourists (destination-specific attributes).

According to Ryan (1991 in Pitana and Gayatri 2005: 67-68) various push factors for a person to take a tour consists of (1) escape, (2) relaxation, (3) play, (4) strengthening family bonds, (5) prestige, (6) social interaction, (7) romance, (8) educational opportunity, (9) selffulfillment, and (10) wish-fulfillment. Escape, relaxation, and play is a physical motivation because it aims to let go self-saturation of daily work, relaxation, and enjoy the joy through various games / activities at tourist destinations; Strengthening family bonds, social interaction, and romance are great motivations social in nature with various activities aimed at strengthening kinship, social interaction with colleagues or with local communities who visited, and made ends meet of affection and romance; Educational opportunity is motivation related to someone's desire to see something new ones, study other people or areas, or to find out other ethnic cultures; Prestige is a motivation related to one's desire to show prestige by visiting a destination indicating the class and lifestyle of the tourist; Self-fulfillment is a motivation related to 
someone's desire to self-discovery (selfdiscovery); and wish-fulfillment is motivation related to one's desire to realize dreams that they had long aspired to, for example the desire to do spiritual tourism.

Pull factors according to Crouch (in Kassean and Gassita 2013) contributing to provide experiences for tourists both positive and negative impressions of a destination. These pull factors are the service infrastructure and the destination environment. Service Infrastructure consists of (1) transportation and travel services, namely services in the field of travel and transportation for tourists for example road, railroad, airport, sea and terminals or stations; (2) accommodation services, namely services in the field of accommodation/services lodging for tourists; (3) recreation and attraction services, namely facilities and services at the time of organizing tourist and recreational attractions for tourists; (4) shopping services, namely facilities and services given for shopping activities for tourists; and (5) food and beverage services, namely facilities and services provided with a variety of food and beverage offerings for tourists.

Chang (2007) indicated that the motives for package tour travellers are relaxation and pleasure, social relationships, socio-economic factors and sociopsychological needs. On the other hand, Correia et al. (2007) identified the travel motivations to exotic destinations: knowledge, leisure, socialization, facilities, core attractions and landscape features. The objective of this study is to explore factors influencing Indonesian tourist to travel to Turkey during pandemic.

\section{Covid-19 Impact on Tourism}

All sectors of the economy suffered a great deal from the lockdown, quarantine, and border closures (Goodell, 2020), tourism and hospitality industries appeared as the biggest (and most immediate) losers of the crisis (Gössling, Scott, \& Hall, 2020). The closed borders prevented scheduled flights and the quarantine measures imposed by the governments limited the opportunities to travel to a great extent (Nicola et al., 2020). Moreover, many tourism businesses went into default or registered huge losses, because of limited travel consumption (Wen, Kozak, Yang, \& Liu, 2020). As the growth of infections started to slow down, governments commenced strategies to resume travel and restore economic growth (Fakhruddin, Blanchard \& Ragupathy, 2020; Collins, 2020).

In Indonesia, Covid-19 pandemic directly impact the hotel occupancy, food and beverage, theater and, cinema, tourism and creative economy activities, tour and travel agency. The risks of the pandemic are temporary closure of hotels and restaurants to be permanent closing, defaults on investment loans and working capital loans, and reduction of employees or termination of employment.

To revive the economy of the tourism sector during a pandemic, the Turkish government issued a Safe Tourism Certification program and the Indonesian government used the CHSE (Cleanliness, Health, Safety, and Environment) certification program. This program aims to enable the tourism industry to revive during a pandemic and provide a guarantee of security to tourists that traveling during Covid-19 pandemic.

\section{Turkey Safe Tourism Program}

Turkey has announced a Safe Tourism Certification program, launched to coincide with the start of the 2020 summer season. The Safe Tourism Certification, which is issued under the leadership of the Ministry of Culture and Tourism and run in partnership with the Ministry of Foreign Affairs, covers a broad range of safety measures taken towards transport, accommodation and health conditions of both hospitality employees and tourists. The certificate, which has been granted by international certification institutions, validates the execution of high levels of health and hygiene requirements at airline companies, airports (and other transport stations) accommodation outlets and food and beverage facilities. The new certification program is made up of four main pillars, covering health and safety of passengers, health and safety of employees, precautions taken at facilities and precautions taken in transportation (Republic 
Of Turkey Ministry Of Culture And Tourism, 2020).

Like many countries, Turkey has been hit hard by coronavirus. The country has experienced several waves of the pandemic. Visitors during this time are advised to follow health safety precautions, such as regularly wash hands, wear a mask, and maintain social distancing. To enter the country, travelers must comply with Turkey's coronavirus travel and entry restrictions. One requirement for entry during the pandemic is to complete a Travel Health Certificate for Turkey online before setting off.

CHSE (Cleanliness, Health, Safety, and Environment)

CHSE began to be implemented in the tourism sector and creative economy in Indonesia since September 2020. The CHSE was made based on the Decree of the Minister of Health on Health Protocols in Places and Public Facilities in the Context of Prevention and Control of Covid-19. The goal is to increase efforts to prevent and control Covid-19 for people in public places and facilities in order to prevent the occurrence of new epicenter or clusters during the pandemic period.

CHSE is applied to the tourism sector and the creative economy in Indonesia. Tourism consists of: Hotels, Restaurant, Attractions, Homestay, Travel business, Guide, SPA, MICE, and Special Interests. Creative Economy consists of: Cinema, Performing arts, Music, Fine art, Fashion, Culinary, Craft, Photography, and Game rides. This program will be implemented by providing CHSE certification for tourism entrepreneurs and the creative economy. This certification will prove that business actors have implemented and improved health protocols in their respective businesses. In addition, tourists and the public can feel secure by complying with the CHSE health protocol standards. Apart from being a step by the government in restoring the national economy, CHSE Certification is also an effort for business owners to restore public trust by enhancing their brand image (Indonesia Tourism Ministry, 2020).

\section{RESEARCH METHOD}

The goal of descriptive research is to describe a phenomenon and its characteristics. This research is more concerned with what rather than how or why something has happened. Therefore, observation and survey tools are often used to gather data (Gall, Gall \& Borg, 2007). In such research, the data may be collected qualitatively, but it is often analyzed quantitatively, using frequencies, percentages, averages, or other statistical analyses to determine relationships. Qualitative research, however, is more holistic and often involves a rich collection of data from various sources to gain a deeper understanding of individual participants, including their opinions, perspectives, and attitudes. Qualitative research collects data qualitatively, and the method of analysis is also primarily qualitative. This often involves an inductive exploration of the data to identify recurring themes, patterns, or concepts and then describing and interpreting those categories. Of course, in qualitative research, the data collected qualitatively can also be analyzed quantitatively.

This study aims to explore Turkey's Safe Tourism program and Indonesian tourist push and pull factors to travel to Turkey during the pandemic. For achieving the research objectives the data were collected from secondary sources; researches, journals, articles, and statistical reports. Primary data were collected through interviews and observations of tourists and travel agent guides who already went to Turkey during the pandemic.

\section{RESULT}

According to the Indonesian ambassador to Turkey, Lalu Muhammad Iqbal (2020), Turkey took proper preventive measures before reopening the tourism sector amid the COVID19 pandemic. Turkish government introduced health risk mitigation measures by ensuring the availability of designated hospitals for foreign travelers. The ambassador added that other factors that determine Turkey's success in the tourism sector are the connectivity between 
tourist attractions, airlines with massive networks and incentives, and stimulus package by the government.

During the COVID-19 pandemic, Turkey became the destination country for many Indonesians to vacation. Based on Intan Permatasari Santosa, operational manager of Tour Operations Manager of Nusantara Tour based in Semarang, Central Java, said some domestic tourists or their customers are starting to look to Turkey because Indonesians can already visit them. Turkey becomes the only choice of other countries' destinations that have been opened for tourists to Indonesia, where the visa process is also quite easy because the visa is on arrival and the requirements documents are also simple (Nusadaily.com, 2020).

A combination of pent-up wanderlust and lockdown fatigue is driving demand for international travel among Indonesian travelers, with a pick-up in outbound tourism bookings, following the reopening of borders in Turkey and the UAE. According to Fonny Wijaya, general manager at Tripuri Wisata said that the agency has sent more than 10 tour groups to Turkey since the end of July 2020. At first, it was a bit difficult for them to sell the Turkey package because people were still worried about Covid-19. However, after the first and second groups traveled, demand began to increase, especially bookings for departures from October to December 2020. Interestingly, the demand was not only flowing from Jakarta but also small cities in Java, such as Bondowoso in East Java even though the number was still small, with only 15 to 20 people per departure. One of the reasons the Turkey tour package was sold because this country has winter. Winter in Turkey gaining appeal in recent years as an alternative destination among Indonesian tourists who desiring to see snow (TTG Asia, 2020).

Based on observations from the Instagram account of travel agents in Indonesia, after the Turkish government announced Safe Tourism to Turkey, Indonesian travel agencies started selling tour packages to Turkey. The tour packages that are sold by these agents are considered cheap because with only around
1000 dollars Indonesian tourists can join a tour package to Turkey with an airline ticket, hotel, transportation, meals, and insurance facilities. These tour packages have proven to attract Indonesian tourists to travel to Turkey, recorded at Soekarno Hatta Airport in Jakarta, as many as 5,494 people in October 2020 who flew via Turkish Airlines (Angkasa Pura, 2020).

\section{Picture 1.Turkey Tour Package}

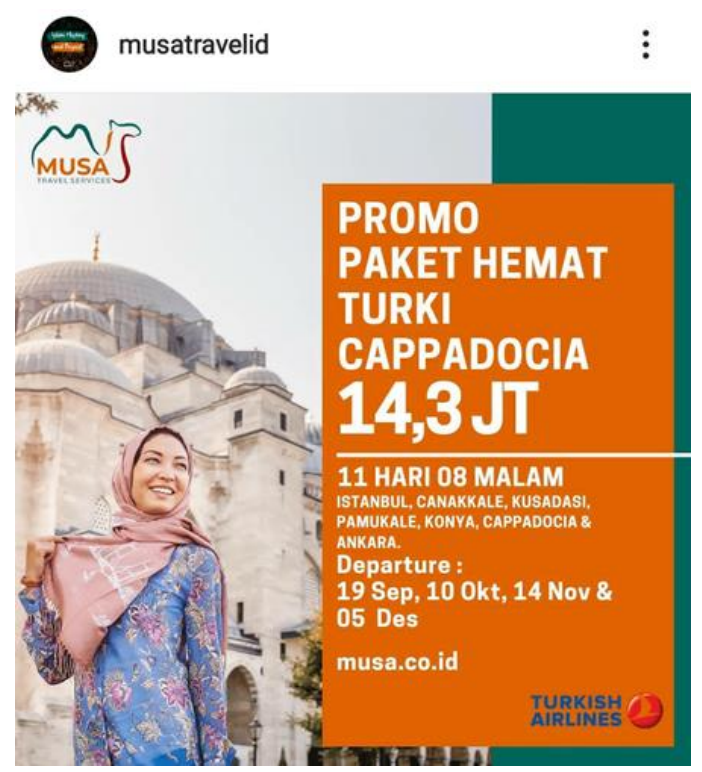

Source: instagram/musatravelid

Until the beginning of 2021, tour packages to Turkey are still the main package sold by travel agents in Indonesia even though there are several other countries that have opened tourism for Indonesian tourists such as Dubai and Egypt. According to Musa Travel tour guide, during this pandemic, travel agents also prepared agreements with the tour participants regarding cancellations and delays in departures due to government policies that may change due to the current pandemic conditions. The regulations that stipulate that every Indonesian tourist must be quarantined after returning from abroad, makes this travel agent temporarily suspend the departure of tour packages to Turkey in January-February 2021. 
Table 1. Turkey Tour Package

\begin{tabular}{|c|c|c|c|c|}
\hline Travel & Price & $\begin{array}{l}\text { Promotion } \\
\text { Date }\end{array}$ & Travel Date & Package \\
\hline $\begin{array}{ll}\text { Raja } & \text { Holiday } \\
\text { Indonesia } & \\
\end{array}$ & $\$ 993$ & 15-Jul-20 & Oct - Nov 2020 & $\begin{array}{l}\text { Wonderful Turkey } \\
\text { 10D8N }\end{array}$ \\
\hline AntaVa & $\$ 899$ & 20-Jul-20 & Aug - Dec 2020 & $\begin{array}{l}\text { 10/11 Days Best of } \\
\text { Turkey + Bhosporus } \\
\text { Cruise }\end{array}$ \\
\hline Panorama JTB & $\$ 993$ & 25-Jul-20 & $\begin{array}{l}\text { Aug }- \text { Dec } \\
2020\end{array}$ & $\begin{array}{l}\text { 8D Turkey - } 7 \\
\text { Churches }\end{array}$ \\
\hline Musa Travel & $\$ 1,021$ & 27-Jul-20 & $\begin{array}{l}\text { Sep }- \text { Dec } \\
2020\end{array}$ & $\begin{array}{l}\text { Promo Paket Hemat } \\
\text { TurkiCappadocia }\end{array}$ \\
\hline Aviatour & $\$ 879$ & $26-0 c t-20$ & $\begin{array}{l}\text { Oct }- \text { Nov } \\
2020\end{array}$ & $\begin{array}{l}9 / 10 \text { Days Mono } \\
\text { Turkey Bosphorus }\end{array}$ \\
\hline Dwidaya Tour & $\$ 950$ & 29-Jul-20 & \begin{tabular}{|l} 
Sep 2020 - Mar \\
2021
\end{tabular} & $\begin{array}{l}\text { 11D Value Deals } \\
\text { Turkey + Taksim }\end{array}$ \\
\hline Wish Travelers & $\$ 893$ & 6-Nov-20 & Dec-20 & 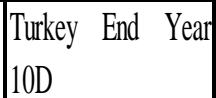 \\
\hline
\end{tabular}

Source: processed by researcher

The Turkish government implements a Safe Tourism program to increase the number of tourists who come to visit Turkey. According to a guide who visited Turkey during a pandemic, tourism in Turkey during a pandemic was quite safe because the situation in Turkey was empty of tourists. Health protocols (wearing masks, washing hands, and keeping distance) were everywhere. At hotels and tourist attractions, tourists will be checked first before entering the area.

Based on the tourist who visited Turkey during the pandemic, they felt safe because the tour guide was always reminding them to keep the health protocols. The tour participants felt happy to be able to travel during the pandemic, the result based on responses from tour participants during the Covid-19 Pandemic.

The existences of Indonesian tourists traveling to Turkey strengthen the survey results published by the Google Consumer Survey in June 2020 (Pikiran Rakyat, 2020). A survey conducted by Google Consumer Surveys has revealed that a large number of Indonesians are planning to wait at least another year before traveling abroad again. According to the survey, which conducted across 17 countries including Indonesia between April and May 2020, some 44 percent of Indonesian respondents plan to wait for more than a year before vacationing overseas, while 17 percent will consider doing so in the next three months. In regard to which countries these travelers would like to visit in the next three months, 34 percent said they wanted to visit Asia Pacific countries, meanwhile, 23 percent preferred to travel to nearby cities. Google also found that the traveling behavior of Indonesian citizens tends to change after the Covid-19 pandemic ends. There are three things that they are most concerned about, namely security and cleanliness priorities, discounted prices and flexibility, and short-term preferences. Other important factors mentioned were an improvement in hygiene standards (24 percent), free face masks or sanitizer wipes (21 percent), and no changes or cancellation fees (16 percent). According to one of the tour guides, the factors that make Indonesian tourists buy this tour package are due to security guarantees in the form of a Safe Tourism program from the Turkish government, travel tours with health protocols by providing health kits, and submitting evidence of health or negative covid-19 letters before leaving, affordable prices and good facilities. Then, there is a refund of the tour package fee if the tour participant's test results are positive, and insurance that covers Covid-19 if the tourist is positive during traveling.

\section{CONCLUSION AND SUGESTION}

Indonesia travel agencies were selling Turkey tour packages because there are demands and purchases. A combination of pent-up wanderlust and lockdown fatigue is driving demand for international travel among Indonesian travelers. The Safe Tourism program offered by the Turkish government proved influential enough to attract Indonesian tourists to travel to Turkey during the pandemic. Travel agents provide full package facilities to make it easier for tourists who want to travel to Turkey, they also provide insurance 
and guaranteed returns if tourists cannot leave because of Covid-19.

The Safe Tourism program offered by the Turkish government proved influential enough to attract Indonesian tourists to travel to Turkey during the pandemic. Turkey is attracting Indonesian tourists because Turkey is one of the few countries that already open to visit, with beautiful natural attractions, full packages facilities, and affordable prices. Consistent with Google consumer survey results, important factors that influence Indonesian tourist travel to Turkey are security, cleanliness priorities, discounted prices, hygiene standards, and no changes or cancellation fees.

The condition of Turkey itself was much quieter than before the pandemic, which made Indonesian tourists comfortable while traveling because they did not interact much with other people besides tour participants, which only around 10-20 people. This research also found that tour guides play an important role in tourism during a pandemic. The tour guide had to remind and monitor tour participants to always pay attention to health protocols while traveling in Turkey.

The tourism sector business such as travel agents has been greatly affected by Covid-19, they still have to sell tour packages so that their companies can survive this pandemic. They try to sell packages by applying health protocols regulated by the Indonesian government and the Turkish government. The risk of being exposed to Covid-19 still exists, therefore prevention needs to be done by undergoing health protocols while traveling and showing negative covid-19 test results.

\section{SUGGESTION}

Until now, it still unknown when the Covid-19 pandemic will end, while the tourism sector is a job opportunity for millions of people in the world. Recovering tourism during a pandemic is not easy, but running a Safe Tourism program is expected to attract Indonesian tourists to travel during a pandemic, both domestic and international tourism.
Further research should be carried out to recover tourism during a pandemic and after the pandemic has ended.

\section{REFERENCES}

[1] Statista. (2020). Number of outbound travelers from Indonesia from 2010 to 2019.

https://www.statista.com/statistics/726892 /number-of-outbound-travelers-indonesia. Accessed on December 23, 2020.

[2] Angkasa Pura II. (2020). Penerbangan Rute Internasional di BandaraSoekarnoHatta Makin Sibuk [PressRelease]. https://angkasapura2.co.id/event/pers/576penerbangan-rute-internasional-dibandarasoekarno- hatta-makin-sibuk. Accessed on January $4^{\text {th }}, 2021$.

[3] UNWTO World Tourism Barometer and Statistical Annex. (2021). January 2021 UNWTO World Tourism Barometer. (English version) Vol 19, No 1.

[4] George, R. (2004), Marketing South African Tourism and Hospitality, 2nd ed, Oxford, Oxford University Press.

[5] March, R. G., \& Woodside, A. G. (2005), Tourism Behavior: Travelers' Decisions and Actions, CABI Publishing, Cambridge.

[6] Decrop, A. (2006), Vacation DecisionMaking, Wallingford, CABI-Publishing.

[7] Tikkanen, I. (2007), "Maslow's Hierarchy and Food Tourism in Finland: Five Cases". British Food Journal, Vol. 109 No. 9, pp. 721-734

[8] Saayman, M., (2006), Marketing Tourism Products and Destinations: Getting Back To Basics, 2nd ed, Leisure C Publications, Potchefstroom.

[9] Yoon, Yooshik \& Muzaffer Uysal. (2005). An examination of the effects of motivation and satisfaction ondestination loyalty: a structural model. Tourism Management 26 (2005) 45-56

[10]Pitana, I. Gede dan Gayatri, Putu G. (2005). Sosiologi Pariwisata. Yogyakarta: Andi.

[11] Kassean, Hemant \& Rhaalib Gassita. Exploring tourists push and pull 
motivations to visit Mauritius as a tourist destination. African Journal of Hospitality, Tourism and Leisure Vol. 2 (3) - (2013).

[12]Chang, J. C. (2007), "Travel Motivations of Package Tour Travelers", Original Scientific Paper, 55 (2), 157-176

[13] Correia, A., Oom Do Valle, P., \& Moço, C. (2006), "Why People Travel to Exotic Places", International Journal of Culture, Tourism and Hospitality, 1 (1), 45-61.

[14] Goodell, J. W. (2020). COVID-19 and finance: Agendas for future research. Finance Research Letters,35, 101512.https://doi.org/10.1016/j.frl.2020. 101512

[15]Gössling, S., Scott, D., \& Hall, C. M. (2020). Pandemics, tourism and global change: a rapid assessment of COVID19. Journal of Sustainable Tourism. Advance online publication. https://doi.org/10.1080/09669582.2020.17 58708

[16]Nicola, M., Alsafi, Z., Sohrabi, C., Kerwan, A., Al-Jabir, A., Iosifidis, C., Agha, M., \& Aghaf, R. (2020). The socio-economic implications of the coronavirus and COVID-19 pandemic: a 13 review. International Journal of Surgery,78,185-193. https://doi.org/10.1016/j.ijsu.2020.04.018

[17]Wen, J., Kozak, M., Yang, S., \& Liu, F. (2020). COVID-19: potential effects on Chinese citizens' lifestyle and travel.

Tourism Review. Advance online publication. https://doi.org/10.1108/TR03-2020-0110

[18]Fakhruddin, B., Blanchard, K., \& Ragupathy, D. (2020). Are we there yet? The transition from response to recovery for the COVID-19 pandemic. Progress in Disaster Science, 7, 100102. https://doi.org/10.1016/j.pdisas.2020.1001 02

[19] Republic Of Turkey Ministry Of Culture and Tourism. (2020). About Safe Tourism Certification Program. Available at: https://www.tga.gov.tr/ about-safetourism-program/ Accessed on January $19^{\text {th }}, 2021$.

[20] Indonesia Tourism Ministry. 2020. Daftar Pedoman Chse. Available at: https://chse.kemenparekraf.go.id/ Accessed on November 23 ${ }^{\text {rd }}, 2020$.

[21] Gall, M.D., Gall, J.P., Borg, W.R. (2007), Educational research: An introduction $\left(8^{\text {th }}\right.$ ed.). Boston: Pearson.

[22] Maria Elisa Hospita. (2020). Indonesian envoy praises Turkey's tourism sector [Press release]. https://www.aa.com.tr/en/asiapacific/indonesian-envoy-praises-turkeystourism-sector/2040400

[23] Nusadaily.com. 2020. Turkey Becomes the Choice of Tourist Destination for Indonesian People during the Pandemi Period [Press Release]. https://nusadaily.com / en/travel/turkeybecomes-the-choice-of-tourist-destinationfor-indonesian-people- during-thepandemic-period.html Accessed on December $20^{\text {th }}, 2020$.

[24] Maharani, Tiara. 2020. Indonesia sees uptick in travel demand to Turkey and Dubai [Press Release]. https://www.ttgasia.com/2020/10/14/indo nesia-sees-uptick-in- travel-demandto- turkey-and-dubai/ Accessed on January $15^{\text {th }}, 2020$.

[25] Ridhoo Maulaa, Mahdu (Ed) .2020. Data Google: 17 Persen Wisatawan Indonesia Ingin Lakukan Perjalanan ke Luar Negeri 3 Bulan ke Depan [Press Release]. https://www.pikiran- rakyat.com /nasiona/ pr-01398062/data- google17-persen- wisatawan-indonesiaingin-lakukan- perjalanan- ke-luarnegeri-3-bulan-ke-depan?page $=3$.

Accessed on January 15th, 2020. 